\title{
In vivo and in vitro propagation of "macela": a medicinal-aromatic native plant with ornamental potential ${ }^{(1)}$
}

\author{
JULIÁN GUARINIELLO(2), JÉSICA IANNICELLI(2), PATRICIA ANGÉLICA PERALTA(2), \\ ALEJANDRO SALVIO ESCANDÓN(2)*
}

\begin{abstract}
Achyrocline satureioides is a shrub native from South America. In popular medicine it is used in infusions such as digestive, carminative, antispasmodic, eupeptic and emmenagogue. However, its main use is as an ingredient in the liquor industry. Commercial exploitation is carried out through the collection of natural populations in an unsustainable way. The micropropagation of $A$. satureioides will allow its massive propagation and it will settle a base for its domestication. For this, a clone denominated as M1-5 was first propagated by cuttings. Subsequently, nodal segments obtained from young stems were disinfected by a standard method and cultured on MS medium. These shoots were used as a source of explants for subsequent assays. For its in vitro establishment MS medium and WPM were tested. Once the culture was established, the responses of the explants to increasing concentrations of 6-benzylaminopurine (BAP) $(0.0 ; 0.5 ; 2.5$ and $5.0 \mu \mathrm{M})$ with and without $0.05 \mu \mathrm{M} \boldsymbol{\alpha}$-naphthalene acetic acid (NAA) on WPM as basal medium were studied during 35 days. The proliferation of buds, the presence of callus and the number and length of the roots were evaluated. All of the "macela" cuttings in vivo propagated rooted and developed satisfactorily under the conditions tested. The application of $5.0 \mu \mathrm{M}$ BAP alone generated the best multiplication rate, so it was selected as the multiplication medium. De novo shoots rooted spontaneously and finally, transferred to the greenhouse. Here in it was possible to establish a micropropagation protocol not only for the production of plantlets of selected clones but also for the application of biotechnological tools in the development of $A$. satureioides germplasm.
\end{abstract}

Keywords: Achyrocline satureoides, micropropagation, tissue culture, germplasm conservation.

\section{RESUMO}

Propagação in vivo e in vitro de "macela": planta nativa medicinal-aromática com potencial ornamental Achyrocline satureioides é um arbusto nativo da América do Sul. Na medicina popular é usado em infusões como digestivo, carminativo, antiespasmódico, eupéptico e emenagogo. No entanto, seu principal uso é como ingrediente na indústria de bebidas. A exploração comercial é feita através da coleta em populações naturais, de modo extrativista e predatório. A micropropagação de A. satureioides permite a multiplicação massiva dessa espécie e é um reforço para sua domesticação e melhoramento. Para isso, um clone denominado M1-5 foi propagado por estacas. Posteriormente, segmentos nodais obtidos de hastes jovens, desse clone, foram desinfetados pelo método padrão e cultivados em frascos contendo meio MS. Essas brotações foram usadas como fonte de explantes para ensaios subsequentes. Testaram-se no estabelecimento in vitro, o meio MS e o WPM. Uma vez estabelecida a cultura in vitro, estudaram-se as respostas dos explantes em relação a concentrações crescentes 0; 0,5; 2,5 e 5,0 $\mu \mathrm{M}$ de 6-benzilaminopurina (BAP) e adição ou ausência de ácido $\alpha$-naftaleno acético (ANA) $0,05 \mu \mathrm{M}$, em meio basal WPM. A cultura foi monitorada periodicamente por 35 dias, registrando a proliferação de gemas, a presença de calos e o número e comprimento das raízes. Todas as estacas da «macela» propagadas in vivo enraizaram-se e desenvolveram-se satisfatoriamente nas condições testadas. A aplicação de 5,0 $\mu \mathrm{M}$ de BAP por si só gerou a melhor taxa de multiplicação, razão pela qual foi estabelecida como a dose ideal de trabalho. Os brotos gerados de novo enraizaram espontaneamente e foram transferidos para casa de vegetação. Neste trabalho foi possível estabelecer um protocolo de micropropagação para propagação em larga escala de plataforma tecnológica, seja para a produção de mudas de clones selecionados, seja para a aplicação de ferramentas biotecnológicas no pré-melhoramento de germoplasma de "macela".

Palavras-chave: Achyrocline satureoides, micropropagação, cultura de tecidos, conservação de germoplasma.

\section{INTRODUCTION}

Achyrocline satureoides (Inulae-Asteraceae) is a branched semi bush 0.2 to $0.5 \mathrm{~m}$ higher. The leaves are up to $5 \mathrm{~cm}$ long, whitish-tomentose, mainly in the convex side, sessile, simple, alternate, lineal or linear lanceolate.
Chapters are agglomerated in numerous, small and cylindrical thickened balls, with dimorphic flowers. The female ones are filiform and peripheral in a number of 3-6; the hermaphrodites ones are tubular and central, in a number of 1-2. The fruit is an achene with white and rough papus (RETTA et al., 2012). This species is originally from South

DOI: http://dx.doi.org/10.14295/oh.v24i4.1238

(1) Received in 05/06/2018 and accepted in 27/09/2018

(2) Instituto de Genética "Ewald A. Favret”. CICVyA, CNIA, INTA. Hurlingham, Buenos Aires Province, Argentina. *Corresponding autor: escandon. alejandro@inta.gob.ar

Licensed by CC BY 4.0 
America, where it is known as "macela hembra", "vira vira" or "wira wira" (Quechua), "huira huira" (Bolivia), "macela" (Brazil), "yatey caá" (Guaraní), "macela blanca" (Uruguay). It is distributed in southern of Brazil, Paraguay, Uruguay and in the northeast and center of Argentina, where it mainly inhabits in areas of humid climates and sandy soils such as Sierras de San Luis, Córdoba and Tandil, and in the coast of Buenos Aires (GIANGUALANI, 1976).

In popular medicine it is used in infusions as digestive, carminative, antispasmodic, cholagogue, eupeptic and emmenagogue. Phytotherapeutics for oral use are made from its leaves and flowers (Disp No. 2673/99, ANMAT). In this sense, the species is included in the Argentine Food Code since 1995 and it is official in the National Pharmacopoeia of Brazil (RETTA et al., 2012)

It is also used in the manufacturing of cosmetic creams for its high content of flavonoids and antioxidants (NATURA COSMETICS, 2011) and it is mentioned with ornamental potential for potting, rock gardens and bordures (ALONSO et al., 2009). However, its main commercial use is as a flavoring in the beverage industry; specially, as part of the composition of numerous herbal drinks, with or without alcohol.

A. satureioides is a widely studied species; in fact there are numerous reports focused on the study of the biological and medicinal activity of its compounds, as well as in the adjustment of variables for its domestication (DAVIES, 2004), in vivo and in vitro vegetative propagation (KOTIK et al., 2014; SEVERIN et al., 2008; GATTUSO et al., 2007) and even improvement. In this sense, the State University of Campinas - Brazil has recently registered the commercial cultivar CPQBA 2, which was obtained by classical genetic improvement (SERVIÇO NACIONAL DE PROTEÇÃO DE CULTIVARES, 2017).

So far, the size and distribution of the natural populations of $A$. satureioides allow the liquor industry to obtain raw materials from wild collection as source for their manufacturing. However, this methodology will be untenable due to the growing demand for this species and it will increase its vulnerability. In Argentina, the Instituto Nacional de Tecnología Agropecuaria (INTA) has carried out some domestication and cultivation practices. However, there are no national breeding programs or farms that are dedicated to its production.

Tissue culture is perhaps one of the most popular tools of modern biotechnology. In this context, it is highly relevant for the ex situ multiplication of genetic resources, the maintenance sanitary status of materials and the recovery of plants in risk of extinction. It is also the base for the application of biotechniques, such as transgenesis or polyploidization, for the improvement of the production of interesting active principles (IANNICELLI et al., 2018). In addition, tissue culture is a fundamental tool to sustain germplasm banks through micropropagation techniques. It also enables the obtaining of cultivars and the production of synthetic seeds through somatic embryogenesis, which facilitate the transportation and exchange of germplasm be- tween nations due to their axenic nature (ESCANDÓN et al. 2010).

The aim of the present work was to adjust an efficient in vitro micropropagation protocol for $A$. satureioides, in order to establish a technological platform that allows the massive propagation of the species and the consolidation of the domestication and improvement works initiated by our group

\section{MATERIALS AND METHODS}

\section{Plant material}

All the assays were carried out with a clone denominated as M1-5, collected and provided by Miguel Elechosa (2009) from the location of Dique Cruz de Piedra, province

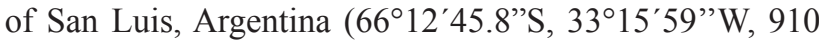
masl). The botanical identification was done by their group and a voucher specimen $\left(\mathrm{N}^{\circ} 6551\right)$ was deposited in the $\mathrm{A}$. M. Molina Herbarium.

The clone was propagated by cuttings in order to ensure a genetically homogeneous source for explants (mother plants).

\section{In vivo propagation}

Vegetative propagation was carried out by cuttings using nodal segments from young stems of the M1-5 clone. A mother plants stock was established. Rooting was induced by the application of indole butyric acid (IBA) (\#57310, Sigma) $3000 \mathrm{ppm}$ powder at the base of the cuttings. Five cuttings were placed per pot $(12 \mathrm{~cm} Æ)$ with a mixture of peat: perlite: vermiculite $(3: 1: 0.5)$, covered with transparent plastic bags and placed in a greenhouse under semicontrolled conditions of light and temperature. The bags were gradually removed. After approximately 30 days, the rooted cuttings were transferred to individual pots $(8 \mathrm{~cm}$ Æ) with a mixture of peat: perlite: vermiculite $(3: 1: 10)$. Periodically, the plants were fertilized with $1 \mathrm{~g} \mathrm{~L}^{-1}$ of hydrosoluble complex fertilizer NPK 18-18-18 with micronutrients.

\section{In vitro propagation}

Nodal segments obtained from $A$. satureioides were used as explants. The donor plant was grown under standard greenhouse conditions and periodically treated with $1 \mathrm{~mL}$ $\mathrm{L}^{-1}$ of Tebuconazole $43 \% \mathrm{v} / \mathrm{v}$ as phytosanitary control. The explants were superficially disinfected by immersion in $70 \%$ ethanol for $1 \mathrm{~min}$, then in $2 \% \mathrm{NaClO}$ with $0.1 \%$ Tween 20 , in constant and gently agitation for $25 \mathrm{~min}$, suggested by Rosso ${ }^{(3)}$. Finally, they were rinsed three times with sterile bidistilled water, dried with filter paper and conditioned for their in vitro introduction. The entire procedure was performed under laminar flow conditions. The explants were then placed in $360 \mathrm{~cm}^{3}$ flasks containing $40 \mathrm{ml}$ of semi-solid MS medium (MURASHIGE and SKOOG, 1962) (0.7\% agar), supplemented with $3 \%$ sucrose. The $\mathrm{pH}$ of the medium was adjusted to 5.8 with $1 \mathrm{~N} \mathrm{KOH}$. Then medium was sterilized for autoclaving at $121^{\circ} \mathrm{C}$ and $1 \mathrm{~atm}$ 
pressure for $20 \mathrm{~min}$. In all experiments, physical culture conditions consisted of a 16 -h photoperiod of light (30 $\mu \mathrm{E} \mathrm{m}^{-2} \mathrm{~s}^{-1}$ ) and a temperature of $25 \pm 2{ }^{\circ} \mathrm{C}$. After 15 days, subcultures were performed in the same medium. The percentage of contamination and the survival of the explants were estimated after 30 days. Once the culture was established, the response to different ionic strength was tested. Twenty binodal segments were transferred to two different basal mediums: MS and WPM (LLOYD and MCCOWN, 1980). The development of the explants was qualitatively compared at 15-20 days. Subsequently, a factorial experiment was performed to compare the in vitro response of $A$. satureioides to 6-benzylaminopurine (BAP) (\#B3408, Sigma) and $\alpha$-naphthalene acetic acid (NAA) (\#N0640, Sigma). Nodal segments of approximately $1.0 \mathrm{~cm}$ length from in vitro-plantlets were transferred to WPM $(0.7 \%$ agar; $3 \%$ sucrose) supplemented with increasing concentrations of $0.0 ; 0.5 ; 2.5$ and $5.0 \mu \mathrm{M}$ BAP, with and without $0.05 \mu \mathrm{M}$ NAA, in all the possible combinations. The experiment was conducted according to a complete randomized design. Two explants were grown in a 60 $\mathrm{cm}^{3}$ flasks, containing $20 \mathrm{~mL}$ of medium, covered with sterile gauze/cotton plugs. Ten flasks per treatment were used (repetitions). Preexisting shoots development, de novo buds proliferation, presence of callus and number and length of the adventitious roots were measured after 35 days. Multiplication rate was assessed by counting the number of shoots per explant.

The data obtained were evaluated by analysis of variance (ANOVA) followed by Tukey test. Significance of results was set at $p<0.05$. The InfoStat software version 2014 (Argentina) was employed (DI RIENZO et al., 2014).

\section{Rooting and acclimatization}

At 75 days after the starting of the experiment, the developed plantlets from preexisting meristems in BAPfree treatments (treatment control and treatment containing only NAA) rooted and were transferred to acclimatization in greenhouse using plastic cups and a mixture of peat: perlite: vermiculite $(3: 1: 1)$. The nylon bags used to make the humidity chamber were gently perforated once per day until no inside condensation was detected. This feature determined the end of the acclimatization stage. Afterwards, plants were grown under standard greenhouse conditions. On the other side, the influence of auxins and cytokinins as a residual effect on rooting was evaluated. Plantlets developed from treatments containing BAP, or nodal segments extracted from them, were transferred to a medium without hormones for rooting. After 30 days, the rooted plantlets were acclimatized as it was described before and their survivals were assessed.

\section{RESULTS}

All the cuttings in vivo propagated of "macela" rooted and developed satisfactorily. These clones were used as a source of explants for all of the assays carried out in this study (Figure 1). After the disinfection protocol, 35\% of the treated explants were recovered. Contamination, mainly with fungi (35\%) and bacteria (28\%), was observed and there were some cases of necrosis. The survived explants showed satisfactory growth.

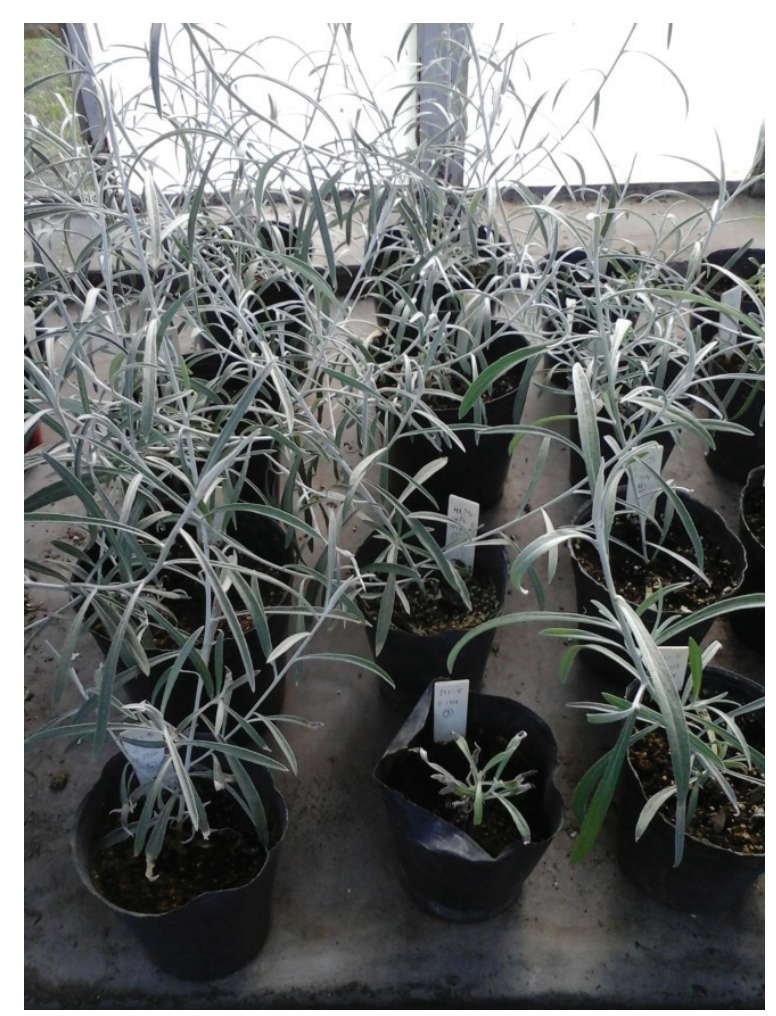

Figure 1. M1-5 mother plants of $A$. satureioides in the greenhouse. These clones were used as a source of explants for the micropropagation trials. 
At early stages of the culture, leaves development and adventitious roots generation were observed. Afterward, the elongation of the internodes was detected. After 30 days under in vitro conditions, 2-3 nodes per stem were counted (Figure 2). This allowed the obtaining of new explants and the in vitro multiplication.
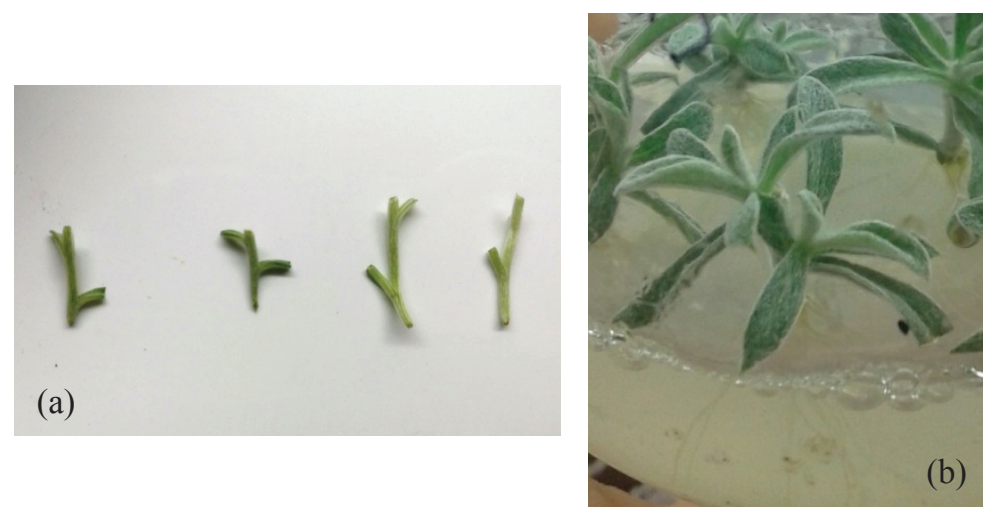

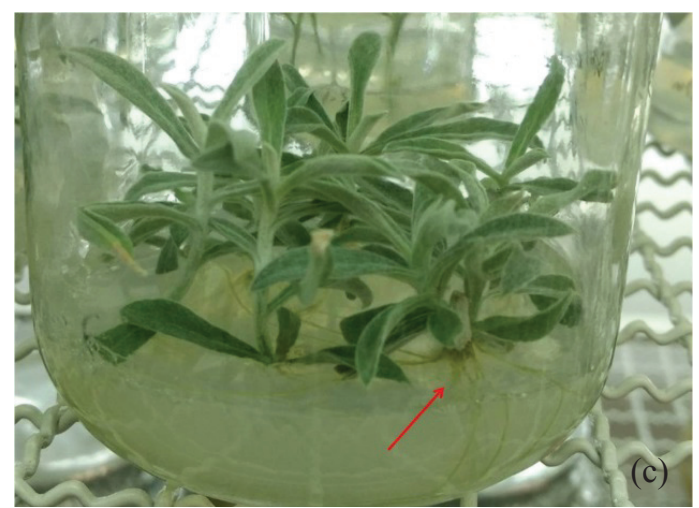

Figure 2. Binodal segments of clone M1-5 of A. satureioides on MS medium, at the beginning (a), 10 days (b) and 30 days (c) of culture. The arrow indicate the neo-formed roots.

The nodal segments of M1-5 after 20 days of culture on MS and WPM base medium showed different responses. The explants on WPM were larger and had better appearance, so this medium was selected for the establishment and multiplication in the following experiments (Figure 3 ).

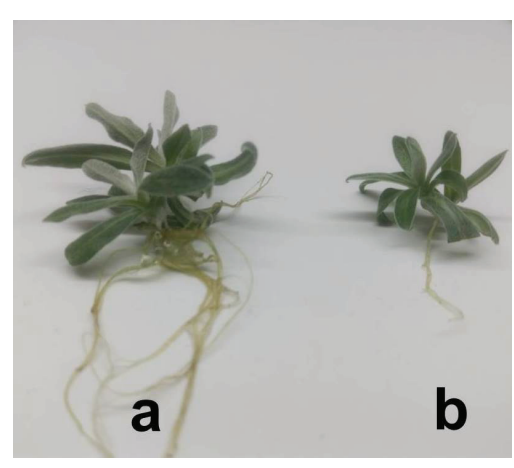

Figure 3. Development of the binodal segments of A. satureioides after 15 days of culture on WPM (a) and MS (b) base medium, respectively.

During the evaluation of the response of the M1-5 clone to the combination of NAA and BAP, development of axillary buds was observed in all the explants after 8-9 days of culture, independently of the growth regulator ratio. Likewise, it was observed that in $98 \%$ of the control explants $(0.0 \mu \mathrm{M}$ BAP; $0.0 \mu \mathrm{M} \mathrm{NAA})$ and in the treatment
$0.05 \mu \mathrm{M}$ NAA, the development of adventitious roots was induced. On the other hand, in the treatments containing 0.5 $\mu \mathrm{M}$ BAP only $50 \%$ of the explant rooted. No rooting was observed in the treatments 2.5 and $5.0 \mu \mathrm{M}$ BAP whereas a thickening was observed at the base of the explants in both treatments (Figure 4). 


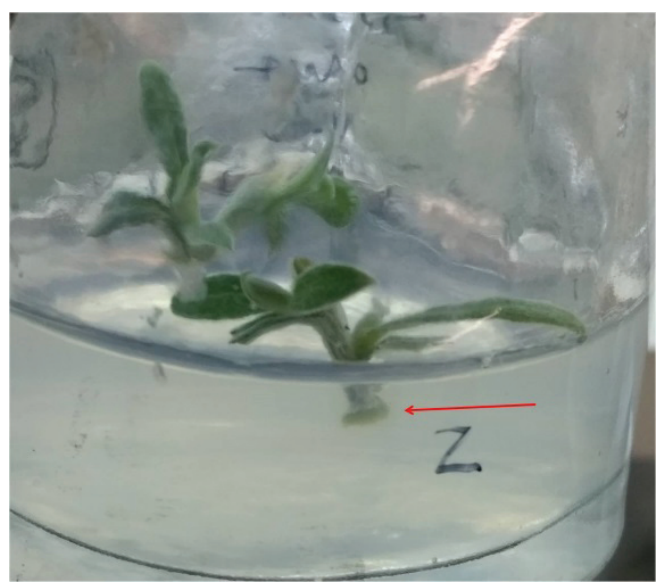

Figure 4. Binodal segments of clone M1-5 of $A$. satureioides on WPM medium supplemented with $5.0 \mu \mathrm{M}$ BAP at 8 days of culture. The arrow indicates the thickening at the base.

After 14 days of culture, it was observed that the lowest number of adventitious roots was induced at the highest BAP concentration whereas the number of induced roots was higher in treatments containing NAA, with interaction between both growth regulators $(p<0.05)$ (Figure 5).
The treatment with $0.05 \mu \mathrm{M}$ NAA without BAP produced the higher number of roots (5-6). Also, at increasing concentrations of BAP the length of the roots was reduced and deformed leaves and an incipient callus development at the base of some explants was observed.

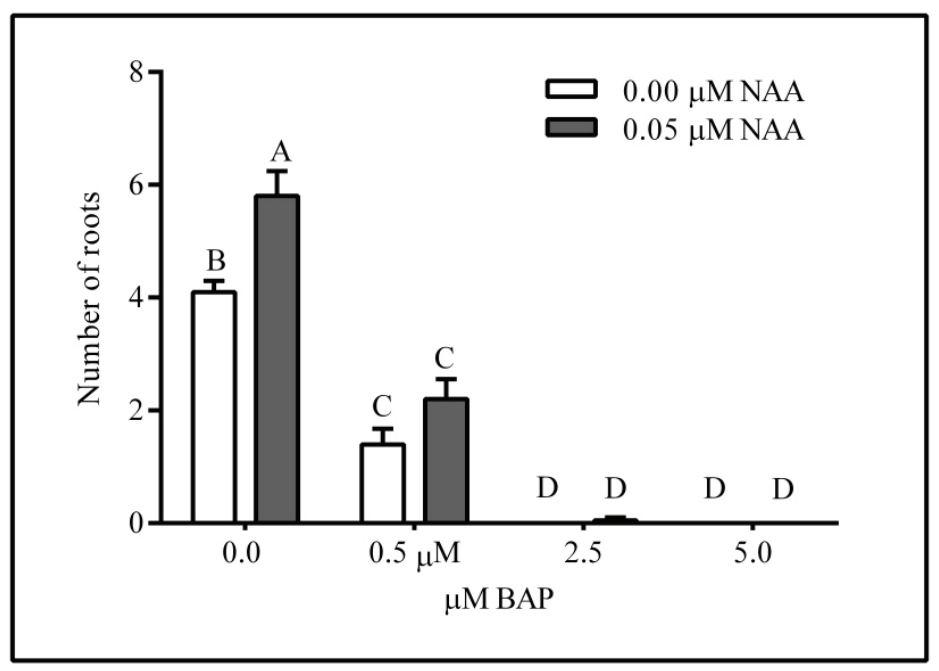

Figure 5. Number of roots per explant at 14 days of culture on WPM medium supplemented with NAA $(0,0.05 \mu \mathrm{M})$ and BAP $(0,0.5,2.5$ and $5.0 \mu \mathrm{M}) . \mathrm{n}=20$. Mean \pm SEM. Means with a common letter are not significantly different according to Tukey $(\mathrm{p}>0.05)$

After 28 days of culture, de novo buds development at the base of the explants was observed in the treatments containing the highest BAP concentrations, 5.0 $\mu \mathrm{M}$ BAP $(p<0.05)$. The multiplication rate measured with BAP was not influenced by the addition of NAA $(p=0.89)$ (Figure 6). 


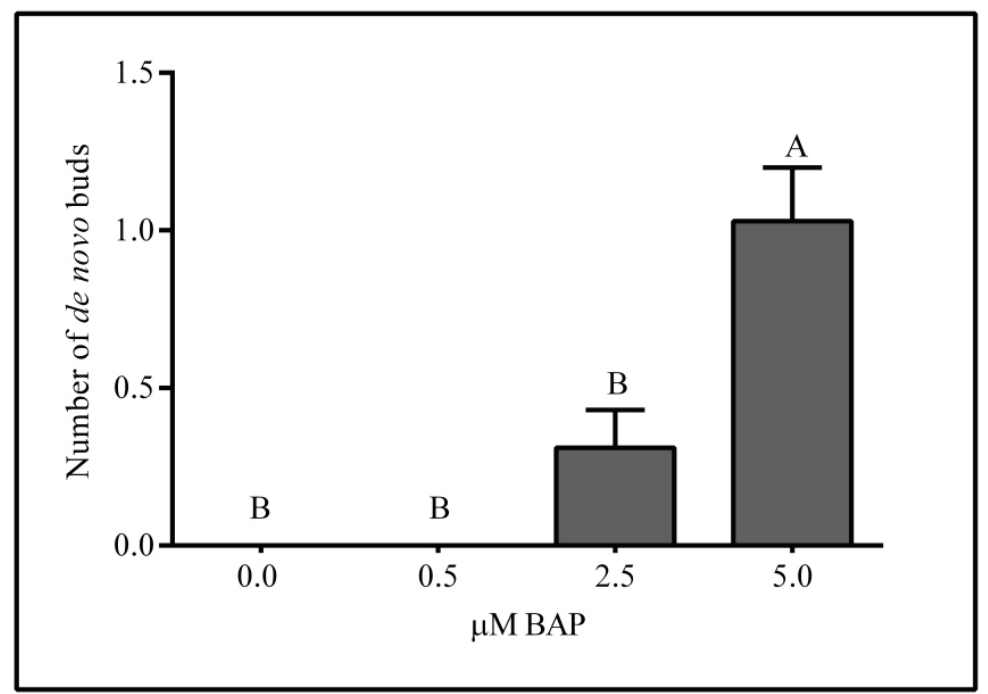

Figure 6. De novo buds at the base of explants at 28 days of culture on WPM medium supplemented with $0 ; 0.5 ; 2.5$ and 5.0 $\mu$ M BAP. $n=40$. Mean \pm SEM. Means with a common letter are not significantly different according to Tukey $(\mathrm{p}>0.05)$.

However, one week later interaction in the response between the concentrations of NAA and BAP was observed $(p<0.05)$. The treatment $5.0 \mu \mathrm{M}$ BAP; 0.0 $\mu \mathrm{M}$ NAA showed the highest number of buds/shoots per explant, including both pre-existing and de novo meristems (Figure 7).

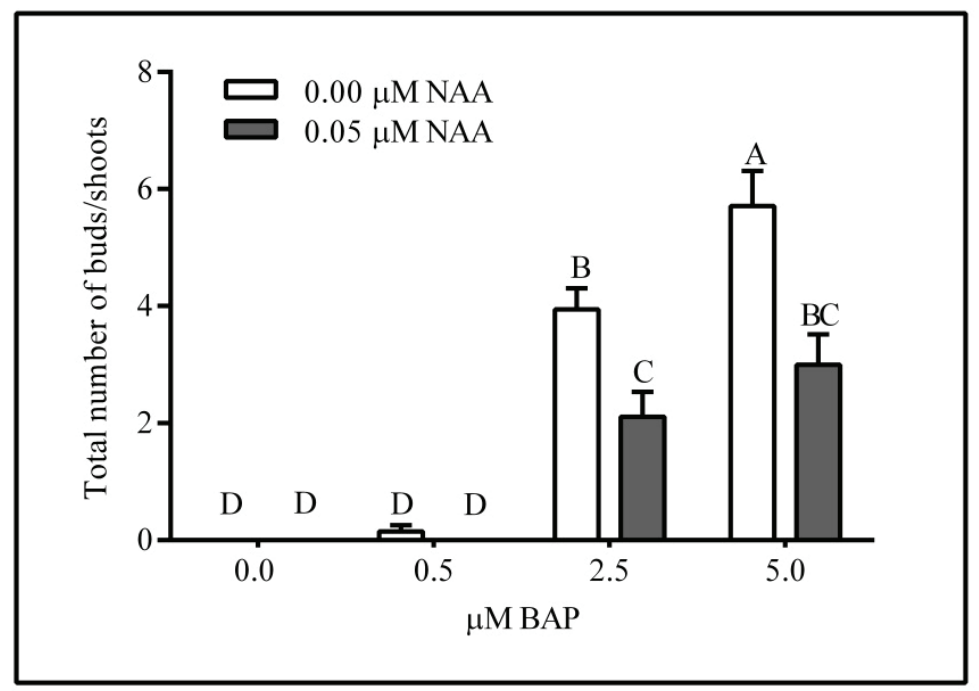

Figure 7. Total number of buds / shoots (de novo generated + pre-existing) in explants cultured on WPM medium supplemented with $\operatorname{NAA}(0,0.05 \mu \mathrm{M})$ and $\operatorname{BAP}(0,0.5,2.5$ and $5.0 \mu \mathrm{M})$ at 35 days. $\mathrm{n}=20$.

Mean \pm SEM. Means with a common letter are not significantly different according to Tukey $(\mathrm{p}>0.05)$

In BAP treatments, a thickening in the base of the explant was observed (see Figure 4). Later, this tissue originated a callus with possible meristems (Figure 8).
However, the incipient leaf primordia generated from the callus showed vitrification, degeneration and, finally, necrosis. 
a)
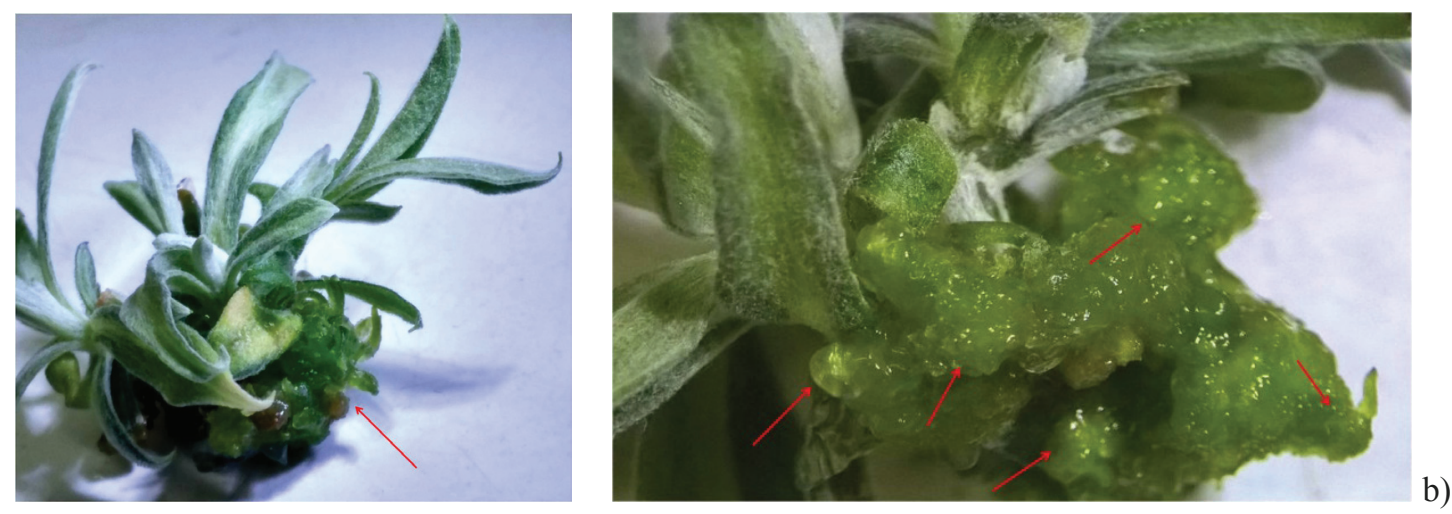

Figure 8. a) General view of a binodal segment on WPM medium with 5.0 $\mu$ M BAP at 28 days of culture. The arrow indicates the callus developed at the base of the explant. b) Enlarged view of the base of the explant showing the development of basal callus. The arrows indicate possible meristematic points.

After 50 days of culture, the state of the explants showed significant changes. The development of the main shoot can be observed from the preexisting bud, as well as the appearance of adventitious buds in the callus at the base of the explants (Figure 9). De novo shoots were transferred to WPM free of growth regulators, where they rooted after one week in this condition (Figure 10). Finally plantlets were transferred to plastic pots under standard greenhouse conditions. After 30 days the ex vitro plant reached a $100 \%$ of survival (Figure 11).

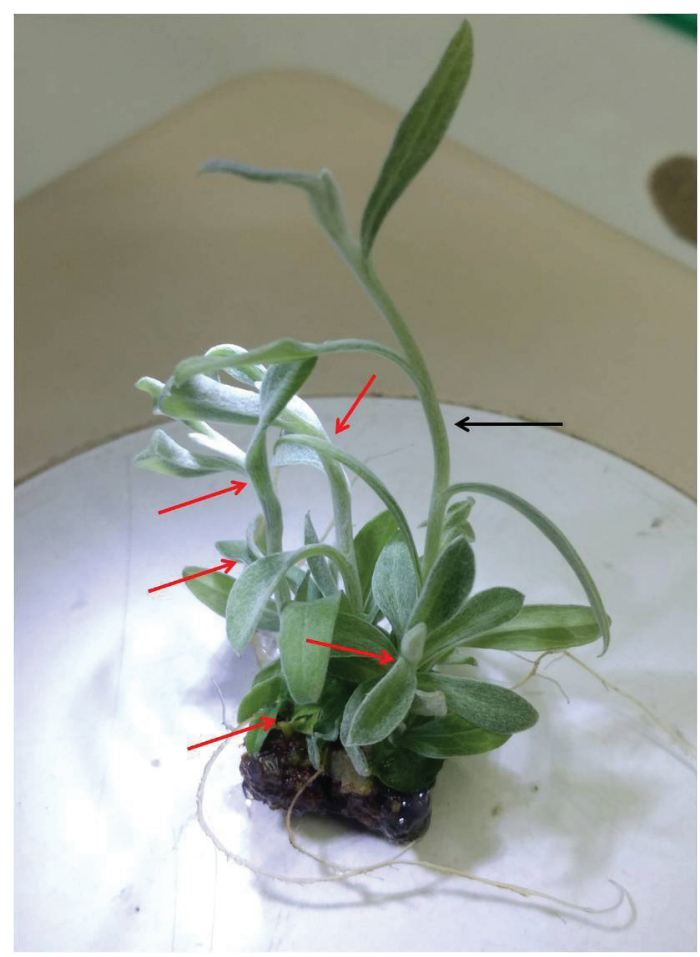

Figure 9. Shoots generated from pre-existing (black arrow) and de novo (red arrows) buds at 50 days of culture on WPM medium with 5.0 $\mu \mathrm{M}$ BAP 


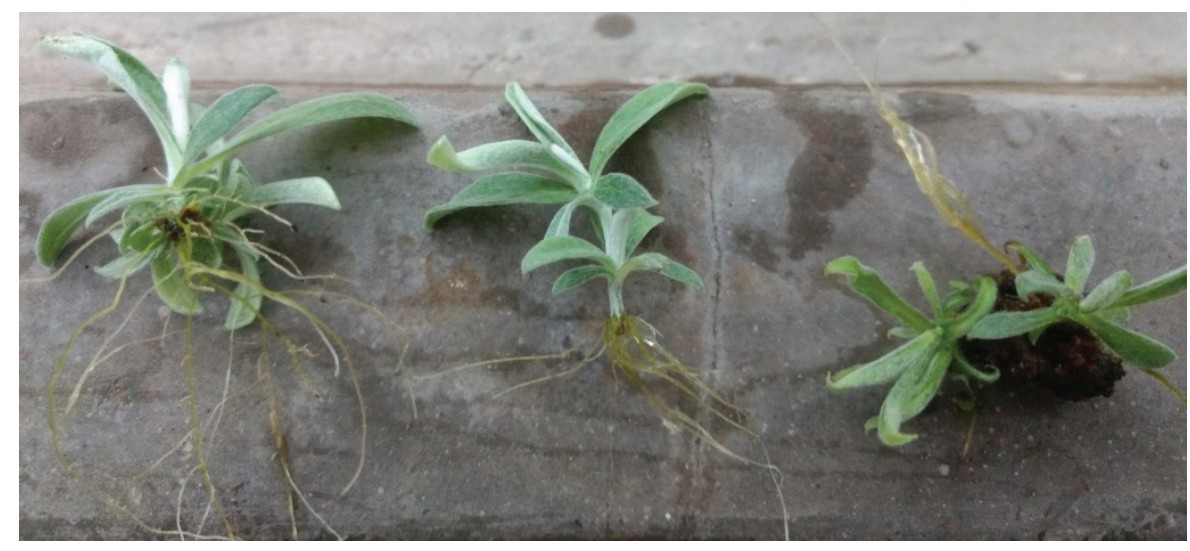

Figure 10. De novo regenerated shoots rooted prior to acclimation in a greenhouse.

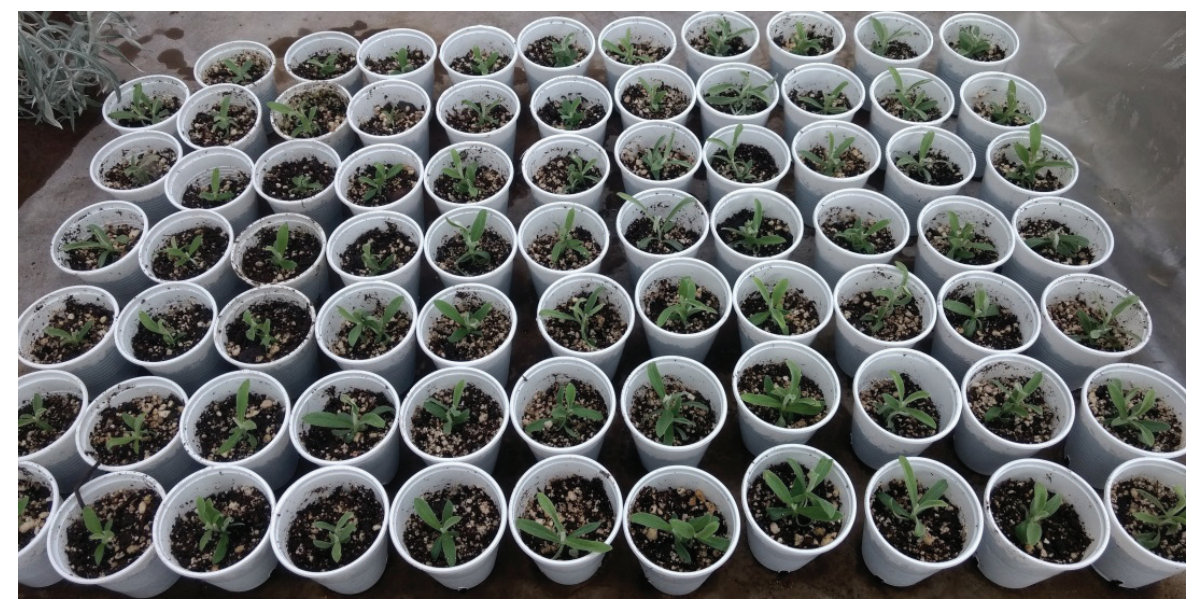

Figure 11. Acclimation of ex vitro plants 15 days after the transplant in the greenhouse.

\section{DISCUSSION}

Although clone M1-5 showed a satisfactory response to in vivo propagation, massive propagation requires the development of a micropropagation system, which not only generates an acceptable multiplication rate but also attends as a platform for future applications of biotechnological technics for the development of the germplasm of this species. The disinfection protocol suggested by Rosso, C. ${ }^{2}$ seemed to be adequate for the introduction and in vitro establishment of $A$. satureioides. As it is indicated in the literature and in the present work, a high disinfection efficiency of the explants was not obtained for this species, possibly due to the dense hairiness that covers the leaves and stems of the plant (SEVERÍN et al., 2008; GATTUSO et al., 2007). However, the survived explants adapted very well to the culture conditions and responded adequately to the experiments.

Regarding in vitro multiplication, although it was used the protocol and genotype proposed by Rosso, $\mathrm{C}^{2}$. the results obtained were not the same. It is possible to speculate that factors such as differences in water quality and/or the reagents used and/or also the operator may have influenced the results in our work. Therefore, based on the results of Bonnecarrère et al. (2009), whose reported a satisfactory in vitro proliferation of $A$. flaccida using WPM, it was decided to compare the response of $A$. satureioides to both hormone-free base media MS and WPM. The differences in the quality and appearance of the regenerated shoots were clear. In fact, WPM produced larger plants than the MS medium on equal conditions. Although WPM has lower nitrogen content than MS, it also has lower sodium content. Bonnecarrère et al. (2009) postulated that for the genus Achyrocline, this element could generate some toxicity, which would explain the lower growth observed in the explants cultivated in MS medium.

In relation to growth regulators, previous reports on the in vitro propagation of $A$. satureoides in semi-solid culture medium using nodal segments suggest that BAP is the most adequate growth regulator. Although, in all cases the obtained multiplication rates were not high, variations were observed according the different authors. Gattuso et al. (2007) using MS base medium (0.75X) supplemented with $1.0 \mathrm{mg} \mathrm{L}^{-1} \mathrm{BAP}(4.4 \mu \mathrm{M} \mathrm{BAP})$, which can be considered comparable to the concentration used in our work, reported 1-2 shoots per explant and concluded that no differences were detected in comparison to the controls. On the other hand, Severin et al. (2008), using the same protocol reported by Gattuso et al. (2007), analyzed the response of $A$. satureoides nodal segments to different cytokinins 
(KIN, BAP and 2iP) and concluded that BAP was the most adequate. In the treatment containing $1.0 \mathrm{mg} \mathrm{L}^{-1} \mathrm{BAP}$ these authors reported 21 shoots per explant after 6 subcultures in the same medium (subcultured every 15 days), which would suggest a multiplication rate for each subculture similar to that reported by Gattuso et al. (2007). In a recent work, Rosso, C. ${ }^{2}$ using the clone M1-5 on MS (1.0X) with $1.0 \mathrm{mg} \mathrm{L}^{-1} \mathrm{BAP}$ recovered up to 7 shoots per explant. In the present work a slightly lower multiplication rate $(6$ shoots per explant) was obtained using a different base medium.

On the other hand, Kotik et al. (2014) studied the regeneration by direct organogenesis of $A$. satureioides using leaves, hypocotyls and cotyledons from plants germinated in vitro as explants. These authors tested different combinations of BAP and NAA on semi-solid MS medium and determined that the best response (a multiplication rate of 4 shoots per explant) was obtained when hypocotyls are grown in medium supplemented with $5.0 \mu \mathrm{M}$ BAP-0.05 $\mu \mathrm{M}$ NAA. Based on this report, in the present work the in vitro response of the nodal segments using a factorial combination between these growth regulators was studied. However, in contrast to the results reported by Kotik et al. (2014), the interaction observed between BAP and NAA was counterproductive for the multiplication of the nodal segments. In this context, the differences observed between Kotik et al. (2014) and the present report can be explained mainly for causes related to the different genotypes used. However, it cannot be ignored that the response of different types of explants (leaves, hypocotyls, cotyledons and nodal segments) to a determined hormonal relationship is also conditioned by other factors such as its architecture, different composition of tissues, the position in which the explant is cultivated and the contact surface with the culture medium. As it was already long established, they can affect the nutrient gradient towards the cellular population responsible for the response (ESCANDÓN et al., 1989).

As Severin et al. (2008) and Kotik et al. (2014) analyzed the effect of other cytokinins (2-isopentenyladenine, kinetin, adenine sulfate and zeatin) on the regeneration of the explants. In agreement with the first, they concluded that BAP (even in combination with NAA) was the most appropriate cytokinin for the in vitro multiplication of $A$. satureioides. These results, together with those commented by Rosso, C. ${ }^{2}$ and those obtained in the present work would indicate certain specificity of BAP for A. satureioides regarding a morphogenic response. In this context, it is interesting to mention the morphogenic responses between 28 and 35 days of culture during the multiplication stage. Thus, this data should be studied and manage in order to develop and improve the germplasm of $A$. satureioides through tissue culture.

In this study the explants rooted fast and spontaneously once they were transferred to WPM free of growth regulators. Also, Kotik et al. (2014) informed spontaneous rooting of explants in a hormone-free medium (MS) and Rosso, C. ${ }^{2}$ also reported spontaneous rooting but using wetted perlite as substrate. In contrast, Gattuso et al. (2007) as well as Severin et al. (2008), using MS 0.75X as a basal medium, had to incorporate auxins in the medium to induce rooting. In both reports, it was postulated that the rooting capacity would be dependent on the genotype used. The result shown in the present work, added to that of Rosso, C. ${ }^{2}$, would support this hypothesis, since although a different basal medium for the development of the shoots (WPM and MS) and a different rooting protocol (semi-solid versus wet perlite) were used, the clone M1-5 rooted and acclimatized satisfactorily. It is also important to highlight that the spontaneous rooting of the de novo shoots would indicate that it is possible to dismiss the residual inhibitory effect of the cytokinin over the rooting, which was observed in the first stages of the culture. Similarly, although the treatment with NAA (without BAP) produced a greater root system (with more roots) than the control treatment, the root system developed by the control $(0.0 \mu \mathrm{M}$ BAP; $0.0 \mu \mathrm{M}$ NAA $)$ was also adequate. In fact, $100 \%$ of survival during acclimation was obtained. All these evidences would indicate the versatility of clone the M1-5 for its in vitro management.

Finally, it is important to highlight that, although the state of the existing natural populations of $A$. satureioides allows the liquor industry to be supplied with raw material from the direct collection, this method is not sustainable over time. If this system continues, it is expected that A. satureioides will follow the same fate of other native aromatic-medicinal species that are in serious risk of extinction.

\section{CONCLUSIONS}

Under the established conditions, the use of WPM as a basal medium produced better quality of plantlets. The treatment containing 5.0 $\mu \mathrm{M}$ BAP generated a greater number of shoots, so it was established as the best concentration for the in vitro multiplication. De novo shoots rooted completely in a week, independently of the previous hormonal treatment and without the need of the addition of auxins into the culture medium. The genotype used showed good aptitude for the in vitro culture of tissues.

It was possible to adjust a micropropagation protocol since the in vitro cycle was completely and satisfactorily ended. Thus, this will allow establishing a technological platform not only for plant production but also the application of biotechnological tools for the development of A. satureioides germplasm for ornamental purposes, or others.

\section{AUTHORS CONTRIBUTIONS}

J.G. (D)0000-0003-4246-0518, J.I. (100000-0003-0265-9100, P.A.P. (D0000-0003-1099-4275, A.S.E. (D0000-0002-9918-3809: contributed in different ways but in the same order of importance for the concretion of this manuscript. 


\section{ACKNOWLEDGMENTS}

The present work was carried out with the financial support of the National Institute of Agricultural Technology (INTA), within the framework of the PNHFA 1106094. Also, the authors thank M. Elechosa for his kindly provision of the clone M1-5, Ana Cecilia Castro for the revision of Portuguese, and Matias Ottaviani for your kind help with the figures of this work.

\section{REFERENCES}

BONNECARRÈRE, V.; BERNÁ, L.; CASTILlO, A. Establishment of micropropagation and cell suspension culture conditions on Achyrocline flaccida (Weinm.) DC. (Asteraceae). Agrociencia, v.13, n.1, p.1-6. 2009.

DAVIES, P. La macela: revisión bibliográfica. In: DAVIES, P. (Ed.). Estudios en domesticación y cultivo de especies medicinales y aromáticas nativas. Montevideo: INIA, 2004. p.194-201.

DI RIENZO, J.A., CASANOVES, F., BALZARINI, M.G., GONZALEZ, L., TABLADA, M., ROBLEDO, C.W. 2014. InfoStat versión 2014. Grupo InfoStat, FCA, Universidad Nacional de Córdoba, Argentina. URL: http:// www.infostat.com.ar

ELECHOSA, M. (Coord.). Manual de recolección sustentable de plantas aromáticas nativas de la región central y noroeste de la Argentina. Buenos Aires: Ediciones INTA, 2009. 64p.

ESCANDÓN, A. S.; HOPP, H. E.; HAHNE, G. Differential amplification of five selected genes in callus cultures of two shrubby Oxalis species. Plant Science, v.63, p.177-185. 1989. DOI: https://doi.org/10.1016/0168-9452(89)90243-4

ESCANDÓN, A.S.; MARINANGELLI, P.A.; PÉREZ DE LA TORRE, M. Avances de la biotecnología en especies ornamentales. In: ECHENIQUE, V.; RUBINSTEIN. C.; HOPP, H. E.; MROGINSKI, L. Biotecnología y Mejoramiento Vegetal II. Buenos Aires: Ediciones INTA, 2010. p.421-435.

GATTUSO, S.; SCANDIZZI, A.; BUSILACCHI, H.; DI SAPIO, O.; SEVERIN, C. Achyrocline satureioides (Lam.) DC.: propagación in vitro a partir de segmentos nodales. Revista de Investigaciones de la Facultad de Ciencias Agrarias-UNR, v.11, p.45-50, 2007.
GIANGUALANI, R. Las especies argentinas del genero Achyrocline (Compositae). Darwiniana, v.20, p.549-576, 1976

IANNICELLI, J.; GUARINIELLO, J.; PERALTA, P.A.; PITTA-ÁLVAREZ, S.; ESCANDÓN, A.S. La biotecnología como herramienta para la conservación y el cuidado de la biodiversidad de las especies aromáticomedicinal nativas. In: SHARRY, S.E.; TRUJILLO, I. Biodiversidad y Biotecnología: un dialogo de saberes. La Plata: Editorial de la Universidad Nacional de la Plata, 2018. p.173-209.

KOTIK, D.; SANSBERRO, P.; LUNA, C. Adventitious bud formation and plantlet regeneration of Achyrocline satureoides - a multipurpose medicinal plant. European Journal of Medicinal Plants, v.4, n.10, p.1200-1209. 2014. DOI: https://doi.org/10.9734/EJMP/2014/8800

LLOYD, G.; MCCOWN, B.H. Commercially-feasible micropropagation of Mountain Laurel, Kalmia latifolia, by shoot tip culture. Combined Proceedings of International Plant Propagators' Society, v.30, p.421-427. 1980.

MURASHIGE, T.; SKOOG, F. A revised medium for rapid growth and bio assays with tobacco tissue cultures. Physiologia Plantarum, v.15, n.3, p.473-497. 1962. DOI: https://doi.org/10.1111/j.1399-3054.1962.tb08052.x

NATURA COSMETICOS S. A. Process for obtaining a standardized extract of quercetin and 3-O-methylquercetin from flowers of Macela (Achyrocline satureioides), and cosmetic and pharmaceutical compositions comprising said extract. Patent WO 2011/073961. 23 de junio 2011.

RETTA, D.; DELLACASSA, E.; VILLAMIL, J.; SUAREZ, S.; BANDONI, A. Macela, a promising medicinal and aromatic plant from Latin America: a review. Industrial Crops and Products, v.38, p.27-38. 2012. https://doi. org/10.1016/j.indcrop.2012.01.006

ROSS, S.; CASTILLO, A. Micropropagación de Achyrocline flaccida (Weinm.) DC. en medios de cultivo líquidos. Agrociencia, v.14, n.1, p1-7. 2010.

SEVERIN, C.; DI SAPIO, O.; SCANDIZZI, A.; TALEB, L.; GIUBILEO, G.; GATTUSO, S. Efecto de algunos fitorreguladores y estudio histológico sobre la regeneración in vitro de Achyrocline satureioides (Lam.) DC. Boletín Latinoamericano y del Caribe de Plantas Medicinales y Aromáticas, v.7, n.1, p.18-24, 2008. 